Article

\title{
Assessing the Carbon Footprint of Biochar from Willow Grown on Marginal Lands in Finland
}

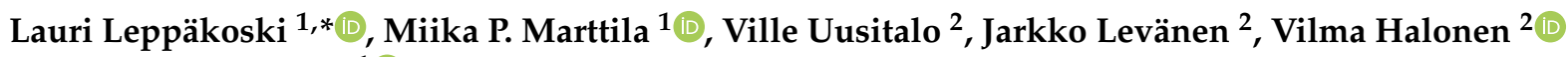 \\ and Mirja H. Mikkilä ${ }^{1}$ (D) \\ 1 Department of Sustainability Science, LUT University, Yliopistonkatu 34, 53580 Lappeenranta, Finland; \\ miika.marttila@lut.fi (M.P.M.); Mirja.Mikkila@lut.fi (M.H.M.) \\ 2 Department of Sustainability Science, LUT University, Mukkulankatu 19, 15210 Lahti, Finland; \\ ville.uusitalo@lut.fi (V.U.); jarkko.levanen@lut.fi (J.L.); vilma.halonen@lut.fi (V.H.) \\ * Correspondence: lauri.leppakoski@lut.fi
}

check for updates

Citation: Leppäkoski, L.; Marttila, M.P.; Uusitalo, V.; Levänen, J.;

Halonen, V.; Mikkilä, M.H. Assessing the Carbon Footprint of Biochar from Willow Grown on Marginal Lands in Finland. Sustainability 2021, 13, 10097. https://doi.org/10.3390/ su131810097

Academic Editor:

Mohammad Aslam Khan Khalil

Received: 6 August 2021

Accepted: 7 September 2021

Published: 9 September 2021

Publisher's Note: MDPI stays neutral with regard to jurisdictional claims in published maps and institutional affiliations.

Copyright: (C) 2021 by the authors. Licensee MDPI, Basel, Switzerland. This article is an open access article distributed under the terms and conditions of the Creative Commons Attribution (CC BY) license (https:/ / creativecommons.org/licenses/by/ $4.0 /)$.

\begin{abstract}
Willow biochar can help to sequestrate carbon. However, biomasses should not be grown on arable lands, as it would increase competition with food production and lead to sustainability issues such as increased food prices and decreased food security. The purpose of this study is to calculate the carbon footprint (CF) of willow biochar in Finland and assess the greenhouse gas compensation potential of marginal lands if they are utilized for willow biochar production. The CF of willow biochar is inadequately assessed together with marginal lands in the literature. A cradle-to-grave Life Cycle Assessment (LCA) of willow biochar was conducted. The results were then applied to assess the total CF of marginal lands. It was found that the CF of willow biochar is $-1875 \mathrm{kgCO}_{2} \mathrm{eq} \mathrm{t}^{-1}$ of dry biochar. Grown on marginal lands in Finland, willow biochar could compensate $7.7 \%$ of yearly agricultural greenhouse gas emissions. On buffer zones, willow biochar could also compensate some of the emissions depending on the zone size. The results of the study support current findings of biochar as a carbon negative product. The study also indicates that willow biochar produced in marginal lands can be used to compensate agricultural greenhouse gas emissions to some extent.
\end{abstract}

Keywords: life cycle assessment; carbon footprint; biochar; pyrolysis; willow; marginal lands; lignocellulosic biomass

\section{Introduction}

In the current climate crisis, the efforts to lower greenhouse gas (GHG) emissions seem to be falling short, and GHG reduction alone is no longer adequate to keep the global temperature rise to below $1.5^{\circ} \mathrm{C}$ of pre-industrial levels. To keep the temperature rise under control, techniques such as carbon capture and storage (CCS) and negative emissions technologies (NET) are required [1]. Smith et al. [2] list seven different NETs that can be used for GHG removal from the atmosphere. One of these NETs is converting biomass to biochar for use as a soil amendment. According to Smith [3], this NET has fewer disadvantages than many other NETs and is therefore an attractive option for GHG removal. This study focuses on the production of biochar and its usage in soil amendment.

A simplified definition of biochar is given by Lehmann and Joseph [4], who describe it as a carbon-rich product obtained from biomass pyrolysis. This process is quite similar to the production of charcoal, but what distinguishes biochar from charcoal is the intended application, which for biochar is usually soil amendment [4]. Biochar can increase porosity, base saturation, water and nutrient holding capacity, and the cation exchange capacity of the soil [5]. In addition to improving soil conditions, biochar can also mitigate GHG emissions. According to Paustian et al. [6], applying biochar on the soil can increase the $\mathrm{C}$ stock of the soil, which results in the net removal of $\mathrm{CO}_{2}$. In soil, biochar is stored for several decades or longer. However, carbon stability can vary depending on soil conditions, 
amendment type and nutrient content [6]. Biochar could also be used in different kinds of filters instead of activated carbon [7] or as a concrete additive to reduce the carbon footprint of buildings [8].

Many types of feedstocks can be used to produce biochar. These feedstocks include all materials of biological origin, such as manure, rendering waste and lignocellulosic biomass [4]. Most of these biomasses are available from agriculture, such as crops and residues (e.g., rice, corn, wheat, soybeans and algae), dedicated energy crops (e.g., switchgrass, miscanthus, fast-growing willow and poplar) [9] and animal waste (e.g., poultry litter and pig manure) [10]. From all these available types of biomass, willow is chosen for this study for two reasons. Firstly, it is the fastest growing and the most high-yielding tree species in Northern Europe [11]; and secondly, willow biochar has been shown to increase clay soil water retention [12]. Thus, willow can provide large amounts of biomass and a biochar product that has great properties for soil amendment.

Biochar has a high carbon sequestration potential. According to the review by Tisserant and Cherubini [13], the carbon footprint (CF) of biochar ranges between net emissions of $0.04 \mathrm{tCO}_{2} \mathrm{eq}$ and a net reduction of $1.67 \mathrm{tCO}_{2} \mathrm{eq}$ per $\mathrm{t}$ of feedstock. The wide range of values is caused by different assumptions, feedstocks, system boundaries and substitution effects, and methodological issues in the life cycle assessment (LCA) studies. In a study conducted by Hammond et al. [14], the best carbon abatement was reached with woody biomasses. Carbon abatement values ranged from 2.9 to $3.9 \mathrm{tCO}_{2} \mathrm{eq} \mathrm{t}^{-1}$ of biochar depending on the type of woody feedstock and the size of the pyrolysis system [14]. An LCA study by Hamedani et al. [15] found that willow biochar can reduce GHG emissions by $2.2 \mathrm{tCO}_{2} \mathrm{eq} \mathrm{t}^{-1}$ of biochar.

The research by Uusitalo and Leino [16] examined the possibility of neutralizing the global warming impacts of crop production using biochar produced from side flows and buffer zone biomass. The study suggests that biochar produced from side flows and buffer zone willow may enable the full neutralization of the GHG emissions of oat production. According to the study, a maximum sequestration potential of $390 \mathrm{kgCO}_{2} \mathrm{t}^{-1}$ oat can be reached with the willow biochar from buffer zones, which would sequester $56 \%$ of oat production emissions (700 kg CO $\mathrm{eq} \mathrm{t}^{-1}$ oat). However, the study did not investigate the CF of the whole life cycle of willow biochar, focusing only on the pyrolysis part. The first primary aim of the current research is therefore to fill that gap and assess the CF of the whole life cycle of willow biochar.

According to the literature reviewed above, in the majority of cases, producing biochar is clearly carbon-negative. However, the origin of the feedstock for biochar should be considered, because the cultivation on arable lands, for instance, can bring some disadvantages. One reason why growing biomass on arable land is not an optimal solution is that the decreased cropland area can lead to higher food prices [17]. It can also lead to the development and a more intensive use of cropland elsewhere, which often means deforestation and increased GHG emissions through land use change [18]. If food and the environmental problems associated with biomass production on croplands are to be avoided, one possible solution could be growing biomass on marginal lands [19,20]. Thus, the second aim of this research is to define the carbon sequestration potential of marginal lands in Finland if they were used to grow willow for biochar production.

In this work, the LCA approach is applied to the assessment of the CF of willow biochar. The LCA method and data used are presented in greater depth in the next two sections. The results and discussion sections consider the main results of the LCA study and the sensitivity analysis. After the sensitivity analysis, marginal lands in Finland and their CF via willow biochar production are assessed. The last part of the discussion considers the issue of willow buffer zones as a way of compensating the GHG emissions of food crop cultivation. Conclusions from the study are drawn and presented in the final section. 


\section{Materials and Methods}

This study is conducted following the LCA methodology described in standards ISO 14040 and 14044, as well as in standard ISO 14067, which gives requirements and guidelines for the quantification of the carbon footprint of products. The LCA methodology standardized by ISO allows for the quantitative assessment of the environmental performance of a system, process or product throughout its whole life cycle. LCA is divided into four steps: goal and scope definition, inventory analysis, impact assessment and interpretation [21,22]. The modeling software is the GaBi professional software (version 9.2.1.68) and the related databases. According to ISO 14067, carbon footprint (CF) is the sum of GHG emissions and GHG removals in a product system and is expressed as $\mathrm{CO}_{2}$ equivalents. The assessment of the $\mathrm{CF}$ is based on an LCA using the single impact category of climate change [23].

The structure of the assessment paper follows the guidelines given in the standards. First, the goal and scope of the LCA are defined, after which the data used for building the LCA model are described in the inventory analysis. The life cycle impact assessment and interpretation are presented in the results and discussion section. The sensitivity analysis is also conducted using the one-at-a-time approach.

\subsection{Goal and Scope of the LCA}

The goal of the LCA is to estimate the CF of willow biochar. The result of the LCA can then be used to analyze the CF of biochar from willow grown on marginal lands. The production system studied is presented in Figure 1. The approach is cradle-to-grave, or, more specifically, the system is studied from willow cultivation to biochar soil amendment. The cultivation of willow planting rods is excluded from the system as well as the materials and manufacturing of the pyrolysis and drying facilities, the district heating network and the manufacturing of other machinery. Furthermore, the effect of the biochar on soil emissions, fertilizer needs in crop cultivation and crop yields are not considered in this study.

The product system studied consists of multiple processes. The functions of these processes are to produce and handle the willow which is the feedstock of the produced biochar and produce the biochar itself. Furthermore, the studied system contains all the processes needed for the transportation of the willow and biochar and the utilization of the excess heat energy from the pyrolysis. The main function of the whole system is the production of biochar for soil amendment, and the functional unit of the study is therefore $1 \mathrm{t}$ of dry biochar stored in soil for 100 years. The allocation between biochar and the excess heat from pyrolysis is avoided with a substitution method. Heat production for district heating is substituted with excess heat from the pyrolysis.

The chosen impact category for the study is climate change. The impact on climate is presented with the CF calculated with the CML 2001-January 2016 methodology. The results are presented in kilograms of $\mathrm{CO}_{2}$ eq per functional unit. The data for the processes were obtained and calculated from the literature sources and the GaBi database. Data specific for Finland were used when available; otherwise, data from other European countries were used as reference values. The data used are presented in Section 3, describing the life cycle inventory. 


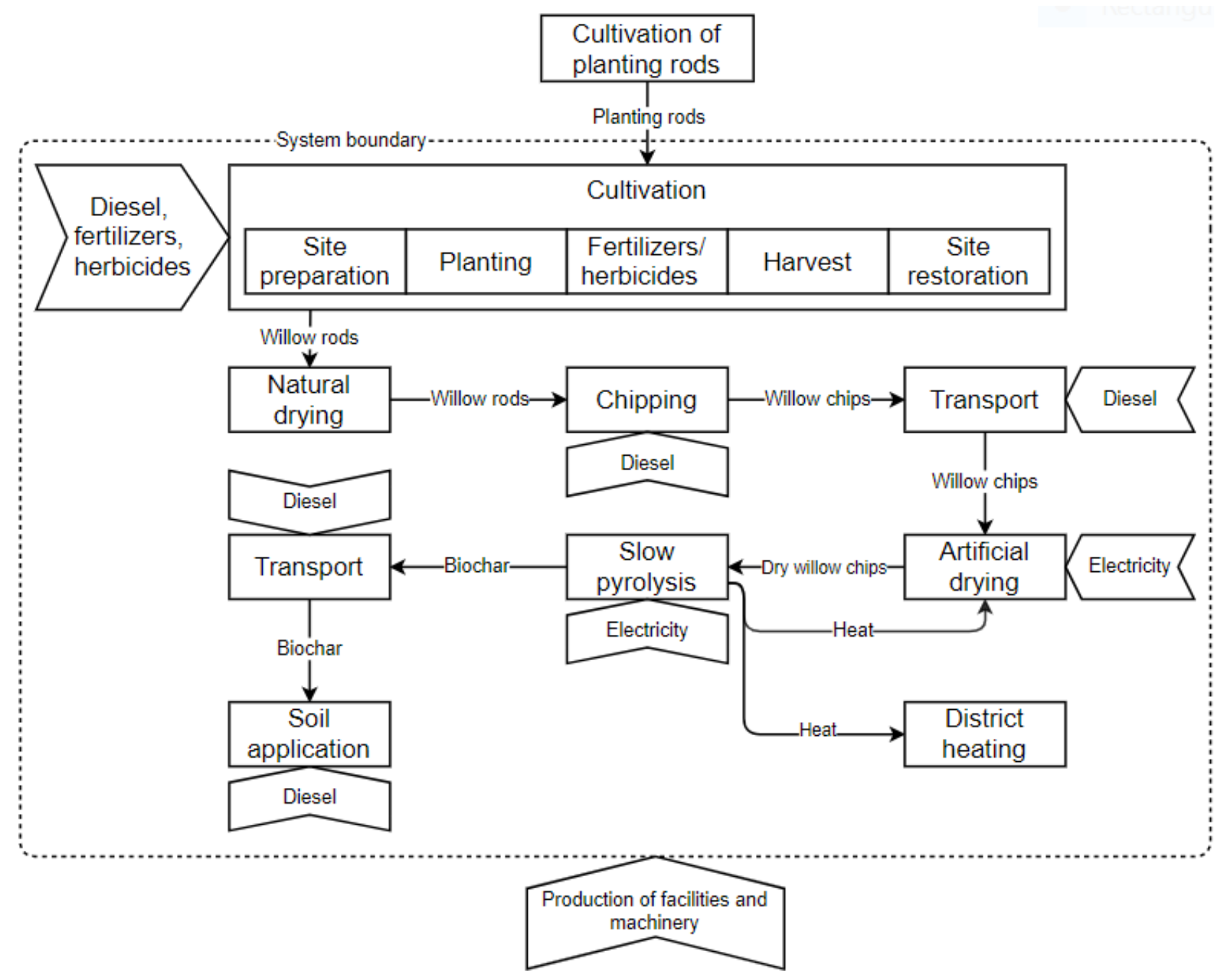

Figure 1. System boundaries and processes of the studied system.

\subsection{Marginal Lands}

To assess the total CF of cultivating willow for biochar production on marginal lands, the area of these lands should be estimated. The total area of marginal lands in Finland was obtained from a report by the Finnish state-owned forestry organization Tapio [24]. Such land includes fields outside of agricultural usage and former peat production land. The following land types were excluded from the study: forest lands, agricultural lands which are covered by agricultural subsidies, areas in nature reserves and urban areas, seashores, yards, valuable traditional biotopes and sites bordered by streams and lakes located in nationally valuable areas, and the immediate surroundings of the sites of endangered species [24]. The assessment is based on geo-spatial analysis, and the values are therefore only estimates. These values are presented in Table 2, in Section 4.2.

Another type of marginal land for which the CF of willow biochar production is assessed are field buffer zones. The full potential of these lands is challenging to estimate because no exact data are available. In this study, we therefore focus on an example field size of 1 ha and calculate how large the buffer zone should be to neutralize the cultivation emissions of the field. We focus on the cultivation emissions of wheat, rye, barley, oat, fava bean, spring rapeseed and potato. The cultivation emissions of the first four crops are obtained from Rajaniemi et al. [25]. The values chosen for this study represent the conventional production of the crops. Rajaniemi et al. [25] also present GHG emissions for cultivation, which includes reduced tillage or direct drilling, but these are excluded from this study. Cultivation emissions for fava bean are obtained from Heusala et al. [26]. 
The values chosen for this study represent a high yield scenario $\left(3600 \mathrm{~kg} \mathrm{ha}^{-1}\right)$ [26], which is in the range of the yield of fava bean in Finland (2382-4553 $\left.\mathrm{kg} \mathrm{ha}^{-1}\right)$ [27]. Cultivation emissions for spring rapeseed are taken from Fridrihsone et al. [28], who present a cradleto-gate LCA of spring rapeseed in Latvia. Cultivation emissions for potato are from Pulkkinen et al. [29]. According to their report, the cultivation emissions of potato are in the range $7-20 \mathrm{gCO}_{2} \mathrm{eq} 100 \mathrm{~g}^{-1}$ of potato, the and potato yield is $34 \mathrm{tha}^{-1}$. This study uses the average cultivation emissions of $14 \mathrm{gCO}_{2} \mathrm{eq} 100 \mathrm{~g}^{-1}$, and the yield of $34 \mathrm{tha}^{-1}$ is used to calculate potato cultivation emissions per hectare. The calculated cultivation emissions for the different food crops are presented in Table 3.

\section{Life Cycle Inventory}

The inputs and outputs of the processes are quantified in this section. All these flows are shown in Table A1, Appendix A.

\subsection{Willow Yield and Plantation Lifetime}

The willow yield depends on the cultivation practices and land type. According to Mola-Yudego [30], the average yield of a short rotation willow plantation in Finland is $6.8 \mathrm{t}$ of dry matter per hectare per year $\left(\mathrm{t} \mathrm{DM} \mathrm{ha} \mathrm{C}^{-1} \mathrm{a}^{-1}\right)$. In a study by Laasasenaho et al. [31], yield drops to $6 \mathrm{tDM} \mathrm{ha}^{-1} \mathrm{a}^{-1}$ when willow is cultivated on peatland in Finland. Carbons Finland Oy [32], a Finnish company providing biochar solutions, presents an average yield of $8 \mathrm{t} \mathrm{DM} \mathrm{ha} \mathrm{ha}^{-1} \mathrm{a}^{-1}$. The average yield for the willow used in this assessment is assumed to be $6.9 \mathrm{t} \mathrm{DM} \mathrm{ha}^{-1} \mathrm{a}^{-1}$, which is a mean value of three yields presented. The average moisture content of willow is 52\% [33], so the yield of fresh willow is $14.4 \mathrm{tha}^{-1} \mathrm{a}^{-1}$.

The lifetime of a willow plantation is approximately 25 years. Harvesting is done 3-8 times during this lifetime, usually every 3-5 years [34]. According to Hytönen [35], the optimal rotation for willow plantation is 3-6 years. In this study, the length of the cycle is assumed to be 4 years, which means six harvests during the plantation lifetime.

\subsection{Tractor Operations}

Next, the diesel inputs for each tractor operation are defined. The main sources for the diesel consumption data are Ahokas [36], Handler and Nadlinger [37] and Murphy et al. [38]. If consumption data are found in multiple sources, averages of the values are used in the assessment. The values used for each tractor operation and how often each operation is required during the willow plantation lifetime are presented in Table A2, Appendix A.

During the site preparation, the land is prepared for willow cultivation. First, the land is sprayed with herbicides to kill weeds. The land is then ploughed and power harrowed [39]. The average fuel consumption for herbicide application used in this assessment is $2.031 \mathrm{ha}^{-1}$ [37,38]. The fuel consumption of ploughing depends on the soil type and the working depth. These are not specified in this study, and therefore the average fuel consumption of $23.971 \mathrm{ha}^{-1}$ is used for ploughing [36-38]. For power harrowing, the fuel consumption used is $61 \mathrm{ha}^{-1}$ [37].

Fertilizers are applied before planting the willow. Later in the plantation lifetime, fertilizers are applied after each harvest, excluding the last. Therefore, the total number of fertilization processes during the plantation lifetime is six. According to Handler and Nadlinger [37], the fuel consumption of a tractor-mounted rotating fertilizer spreader is in the range $1.5-2.51 \mathrm{ha}^{-1}$. For this assessment, an average fuel consumption of $21 \mathrm{ha}^{-1}$ is assumed for fertilizer application.

Willow planting can be done with a modified potato planter, whose average fuel consumption is $10.61 \mathrm{ha}^{-1}$ [38]. The same value is used in this assessment. After planting, the field is rolled, and herbicides are applied again. The average fuel consumption value used in this study for rolling is $3.64 \mathrm{l} \mathrm{ha}^{-1}[37,38]$. The second application of herbicides reduces the heavy growth weed, which would otherwise leave the willow feeble and reduce its winter resistance in the first year. Insecticide use is not necessary, as pest insects should not be a threat to willow growth [34]. 
Willow can be harvested using direct chip, whole rod, billet or bale harvesting [39]. According to Sihvonen et al. [40], whole rod harvesting is the most common harvesting method for willow in Finland. The fuel consumption for whole rod harvesting is $501 \mathrm{ha}^{-1}$ [38]. This value is used in the assessment. After harvesting, the rods are stacked and dried by natural ventilation [39].

At the end of the willow plantation lifetime, the site is restored to its original state. After the last harvest, willow growth is killed with herbicides. This is the third and final time when herbicide application is needed in the plantation lifetime. The field is then cultivated with forestry mulching [39]. For mulching, a fuel consumption of $12.91 \mathrm{ha}^{-1}$ is used in this assessment [37].

In $\mathrm{GaBi}$, these tractor operations are modeled with a single process called GLO: Universal tractor. The process calculates the emissions of diesel burning during the tractor operation. Emissions are based on the fuel consumption. The diesel input for the process was set to the correct value by adjusting the hourly consumption parameter of the process. The production of diesel was modeled with the process EU-28: Diesel mix at filling stations. This process is also used to supply diesel for all transportation processes.

\subsection{Fertilizers and Herbicides}

The amount of fertilizer needed is defined by the amount of nutrient that is removed by harvest. The annual nitrogen offtake of the willow is around $60 \mathrm{~kg} \mathrm{ha}^{-1} \mathrm{a}^{-1}[39,41]$. The other required nutrients are calculated from the desired NPK ratio of 100:14:71 given by Tahvanainen [41]. Thus, the amounts of phosphorus and potassium needed are $8.4 \mathrm{~kg} \mathrm{ha}^{-1} \mathrm{a}^{-1}$ and $43.2 \mathrm{~kg} \mathrm{ha}^{-1} \mathrm{a}^{-1}$, respectively. In $\mathrm{GaBi}$, the NPK ratio does not reflect the amount of elemental phosphorus and potassium but the amount of their oxides phosphorus pentoxide $\left(\mathrm{P}_{2} \mathrm{O}_{5}\right)$ and potassium oxide $\left(\mathrm{K}_{2} \mathrm{O}\right)$. The amount of $\mathrm{P}_{2} \mathrm{O}_{5}$ needed is defined by dividing the phosphorus need by 0.436 and the $\mathrm{K}_{2} \mathrm{O}$ need by dividing the potassium need by 0.830 [42]. The production of these nutrients was modeled in GaBi with the plan GLO: NPK fertilizer mixer.

The amount of $\mathrm{N}_{2} \mathrm{O}$ emissions originating from fertilizer use is defined with the IPCC methodology [43]. In the methodology, it is assumed that $1 \%$ of the nitrogen added with the fertilizers is emitted as $\mathrm{N}_{2} \mathrm{O}$. The conversion factor used for converting $\mathrm{N}$ to $\mathrm{N}_{2} \mathrm{O}$ is $44 / 28$ [43]. Therefore, the amount of emitted $\mathrm{N}_{2} \mathrm{O}$ from a willow field is $0.94 \mathrm{~kg} \mathrm{ha}^{-1} \mathrm{a}^{-1}$.

During the site preparation, glyphosate is sprayed with an application rate of $41 \mathrm{ha}^{-1}$. After the willow has been planted, the field is again sprayed with herbicides, but this time with metazachlor $\left(1.51 \mathrm{ha}^{-1}\right)$ [34]. The in-site restoration of willow growth is terminated with glyphosate spraying of $51 \mathrm{ha}^{-1}$ [39]. DE: Herbicide unspecific process from the GaBi database is used to model the production of these herbicides.

\subsection{Willow Drying}

The willow is dried twice during its life cycle: first, in a storage pile by natural drying and then before pyrolysis with artificial drying. According to two storage experiments $[40,44]$, a moisture content of $26 \%$ is achieved during a storage period of $9-18$ months. The average loss of dry matter during storage is 3\% [40,44]. These assumptions are used in this assessment. A new process was created in GaBi for natural drying which takes willow rods (52\% moisture content) as the input and calculates dry matter losses and a reduction in the willow moisture. The output is a slightly drier willow ( $26 \%$ moisture content).

For artificial drying, the average heat and electricity consumption is $1.251 \mathrm{kWh}$ and $0.070 \mathrm{kWh}$ per $\mathrm{kg}$ of removed water, respectively $[45,46]$. Willow chips are dried to the moisture content of $10 \%$. The production of electricity is modeled in $\mathrm{GaBi}$ with the process FI: Electricity grid mix. The heat needed for drying is assumed to be obtained from the pyrolysis process. A new process was created in Gabi for artificial drying which takes willow chips and electricity as the inputs and dried willow chips as the output. 


\subsection{Chipping and Transportation}

There are multiple places during the lifetime of willow when chipping can be done. However, the most common place is the intermediate storage near the field. This approach minimizes the transportation distance of the willow rods, which are harder to transport than homogenous willow chips [45]. Fuel consumption for chipping is obtained from the study by Spinelli et al. [47]. In their study, the fuel consumption of a trailer-mounted drum chipper was examined for eight different raw materials. The raw materials were different tree species and different parts of trees with different moisture contents. The results varied a little (1.68-2.86 1 per $t$ of fresh wood), but when they were considered as per dry matter output, these variations evened out. According to the study, the average fuel consumption for chipping is 3.211 per $\mathrm{t}$ of DM [47]. This value is used in this assessment. The emissions from this process are calculated with an emissions factor of $2.676 \mathrm{kgCO}_{2}$ per 1 of diesel [43]. It is assumed that there are no mass losses during the chipping. A new process was created in $\mathrm{GaBi}$ for chipping which takes willow rods and diesel as the inputs and $\mathrm{CO}_{2}$ and willow chips as the outputs.

After chipping, the willow chips are transported to the pyrolysis facility. According to Statistics Finland [48], the average transportation distance for forestry products such as firewood, stumps, brushwood and forest chips is $68 \mathrm{~km}$. It is assumed that this is the distance from marginal lands to the pyrolysis facility. Transportation was modeled in $\mathrm{GaBi}$ with the process GLO: Truck-trailer, Euro 6, 34-40 t gross weight/27 t payload capacity, and the distance parameter was set to $68 \mathrm{~km}$.

\subsection{Slow Pyrolysis}

Pyrolysis covers multiple thermal decomposition processes, but when biochar is the desired product, slow pyrolysis is usually applied. The average biochar yield from the slow pyrolysis of biomass is 35\% [49], but the yield can vary in the range of 20-45\% [13]. For willow chips, Hamedani et al. [15] report biochar yield of $33.5 \%$. In this assessment, an average biochar yield of $35 \%$ is assumed. Consequently, $3175 \mathrm{~kg}$ of willow chips (10\% moist.) are required to produce $1 \mathrm{t}$ of biochar.

Crombie and Mašek [50] state that in certain conditions, syngas, a side product of pyrolysis, can be used to maintain the process, thus making it self-sustaining in terms of thermal energy. In this study, it is assumed that the pyrolysis is self-sustaining, and no other energy source except electricity is therefore needed. The average electricity consumption of pyrolysis is taken as $0.126 \mathrm{kWh}$ per $\mathrm{kg}$ of feedstock [51,52].

Additionally, pyrolysis produces excess heat that can be utilized for different purposes. In a model created by Klinar [53], 29\% of the dry biomass energy input was available as hot water or hot air from the process. In their work, the pyrolyzed biomass consisted in wood chips with a moisture content of $10 \%$. The same result was achieved by Roberts et al. [54] when corn stover was pyrolyzed. The moisture- and ash-free heating content of willow chips is $18.6 \mathrm{MJ} \mathrm{kg}^{-1}$ [55], which means that $4.9 \mathrm{MJ}$ of excess heat is available when $1 \mathrm{~kg}$ of willow chips (10\% moist.) is pyrolyzed. In this study, the excess heat is utilized in the artificial drying of the willow chips and district heating. A new process was created in $\mathrm{GaBi}$ for pyrolysis which takes willow chips and electricity as inputs. The outputs of the process are heat for district heating and drying and dry biochar. The production of electricity was modeled with the process FI: Electricity grid mix.

Most of the district heating in Finland is produced in combined heat and power (CHP) facilities. The most commonly used fuels for CHP production are natural gas, coal, peat and wood. In 2018, the average emission factor for district heating was $154 \mathrm{kgCO}_{2} \mathrm{MWh}^{-1}$ [56]. This factor is used in this study when calculating the CF for the substitution of district heating with the excess heat from pyrolysis that is not used in the drying process. A new process was created in $\mathrm{GaBi}$ for substituted district heating. The process takes heat and $\mathrm{CO}_{2}$ as inputs. 


\subsection{Transportation}

Being a small particle, biochar is sensitive to wind losses during handling and transportation. Major [57] reports total losses of 30\%, of which $25 \%$ occur during spreading, $3 \%$ during transportation and $2 \%$ during loading. However, the losses can be decreased by moistening biochar. Hammond et al. [14] assumed handling losses of $1 \%$ and spreading losses of $3 \%$. In this study, the total losses of biochar are assumed to be $5 \%$. The biochar is moistened to a moisture content of $15 \%$ [58]. The transportation of the biochar was modeled with the GaBi process GLO: Truck-trailer, Euro 6, 34-40 t gross weight/27 t payload capacity, and the water for moistening was modeled with EU-28: Tap water from surface water.

\subsection{Application to Soil}

In large and small field trials, the broadcast and incorporate method has been used for the application of biochar to the soil. For broadcasting, spreading moistened biochar in a manure spreader might be a better solution than using a lime spreader, and any ploughing method can be used for incorporating the biochar into the soil, although moldboard ploughing is not recommended because it does not mix biochar very well and might bury the biochar too deep [57]. In this study, the assumed ploughing method is power harrowing, whose fuel consumption is defined in Section 3.2. Fuel consumption for a manure spreader is taken from Handler and Nadlinger [37], who present $141 \mathrm{ha}^{-1}$. The application of the biochar to the soil was modeled with the GaBi process GLO: Universal tractor.

Next, the application rate of the biochar is defined. According to Brandstaka et al. [59], a beneficial application rate in Finnish conditions would be 10-20 $\mathrm{t} \mathrm{ha}^{-1}$. Major [57] reports a positive effect on crop yields with a biochar application rate of $5-50 \mathrm{t} \mathrm{ha}^{-1}$. According to Hammond et al. [14], an application rate of $30 \mathrm{tha}^{-1}$ can increase crop production and decrease fertilizer requirements. As there seem to be a lot of variation in recommended biochar application rates, a calculated average of $25 \mathrm{t} \mathrm{ha}^{-1}$ is used in this study.

\subsection{Biochar Stability and Carbon Content}

Mašek et al. [60] studied the slow pyrolysis of willow chips. In their study, a carbon content of $70.7 \mathrm{wt} \%$ was achieved for the slow pyrolysis of dry biochar using a pyrolysis temperature of $350{ }^{\circ} \mathrm{C}$. Ronsse et al. [61] report a carbon content of $71.3 \mathrm{wt} \%$ when pine wood was pyrolyzed with slow pyrolysis. Rasa et al. [12] pyrolyzed willow at $320^{\circ} \mathrm{C}$, and the elemental analysis of the biochar revealed a carbon content of $74 \mathrm{wt} \%$. In this study, a carbon content following a pyrolysis of $72 \mathrm{wt} \%$ is used, which is the average of the three values.

The decomposition of biochar follows a two-pool behavior. The labile fraction of biochar degrades quickly, and the recalcitrant fraction can stay in the ground for hundreds of years [13]. In their study, Tisserant and Cherubini [13] reviewed 34 different LCA studies on biochar for their most common assumptions. A common assumption for biochar stability was that $68 \%$ of the carbon remains in the soil after 100 years. The same assumption is applied in this study.

When the carbon content $(72 \%)$, biochar stability $(68 \%)$ and losses during transportation and handling (5\%) are taken into account, $465 \mathrm{~kg}$ of carbon is stored for a hundred years when $1 \mathrm{t}$ of dry biochar is applied to soil. With atomic masses of carbon (12) and $\mathrm{CO}_{2}$ (44), one kilogram of carbon will produce $3.67 \mathrm{~kg}$ of $\mathrm{CO}_{2}$. Therefore, storing $465 \mathrm{~kg}$ of carbon means that $1704 \mathrm{~kg}$ worth of $\mathrm{CO}_{2}$ is stored. A new $\mathrm{GaBi}$ process was created for modeling the storage of biochar in soil. The inputs of this process are wet biochar and $1704 \mathrm{~kg}$ of $\mathrm{CO}_{2}$ per $\mathrm{t}$ of dry biochar applied, which represents the $\mathrm{CF}$ of the storage. 


\section{Results and Discussion}

\subsection{Carbon Footprint of Willow Biochar}

A cradle-to-grave LCA was conducted to assess the CF of willow biochar. Based on the LCA, the CF of willow biochar is clearly negative. Using the assumptions in this study, CF of $-1875 \mathrm{kgCO}_{2} \mathrm{eq} \mathrm{t}^{-1}$ of biochar can be achieved, as shown in Figure 2. Storing the biochar in soil, including the sequestrated carbon during willow growth, has the greatest effect on the result $\left(-1704 \mathrm{kgCO}_{2} \mathrm{eq}\right)$, although the replaced district heating $\left(-527 \mathrm{kgCO}_{2} \mathrm{eq}\right)$ also lowers the $\mathrm{CF}$ significantly. The negative $\mathrm{CF}$ from the replaced district heating is caused by the assumption that less heat needs to be produced by CHP plants when excess heat from pyrolysis is utilized for district heating. The biggest emitter during the life cycle is the willow cultivation phase $\left(212 \mathrm{kgCO}_{2} \mathrm{eq}\right)$. Most of the emissions from this phase originate from $\mathrm{N}_{2} \mathrm{O}$ emissions from the use of a nitrogen fertilizer $\left(107 \mathrm{kgCO}_{2} \mathrm{eq}\right)$ and the production of fertilizers $\left(84 \mathrm{kgCO}_{2} \mathrm{eq}\right)$. The $\mathrm{CF}$ for electricity usage during pyrolysis is $84 \mathrm{kgCO}_{2} \mathrm{eq}$, and the fuel usage of chipping contributes $25 \mathrm{kgCO}_{2} \mathrm{eq}$. The $\mathrm{CF}$ for tractor operations is $19 \mathrm{kgCO}_{2} \mathrm{eq}$, for transportation $18 \mathrm{kgCO}_{2} \mathrm{eq}$, and for electricity consumption during drying $10 \mathrm{kgCO}_{2}$ eq. The remaining emissions of $10 \mathrm{kgCO}_{2}$ eq originate from diesel production, soil application of biochar and herbicide production.

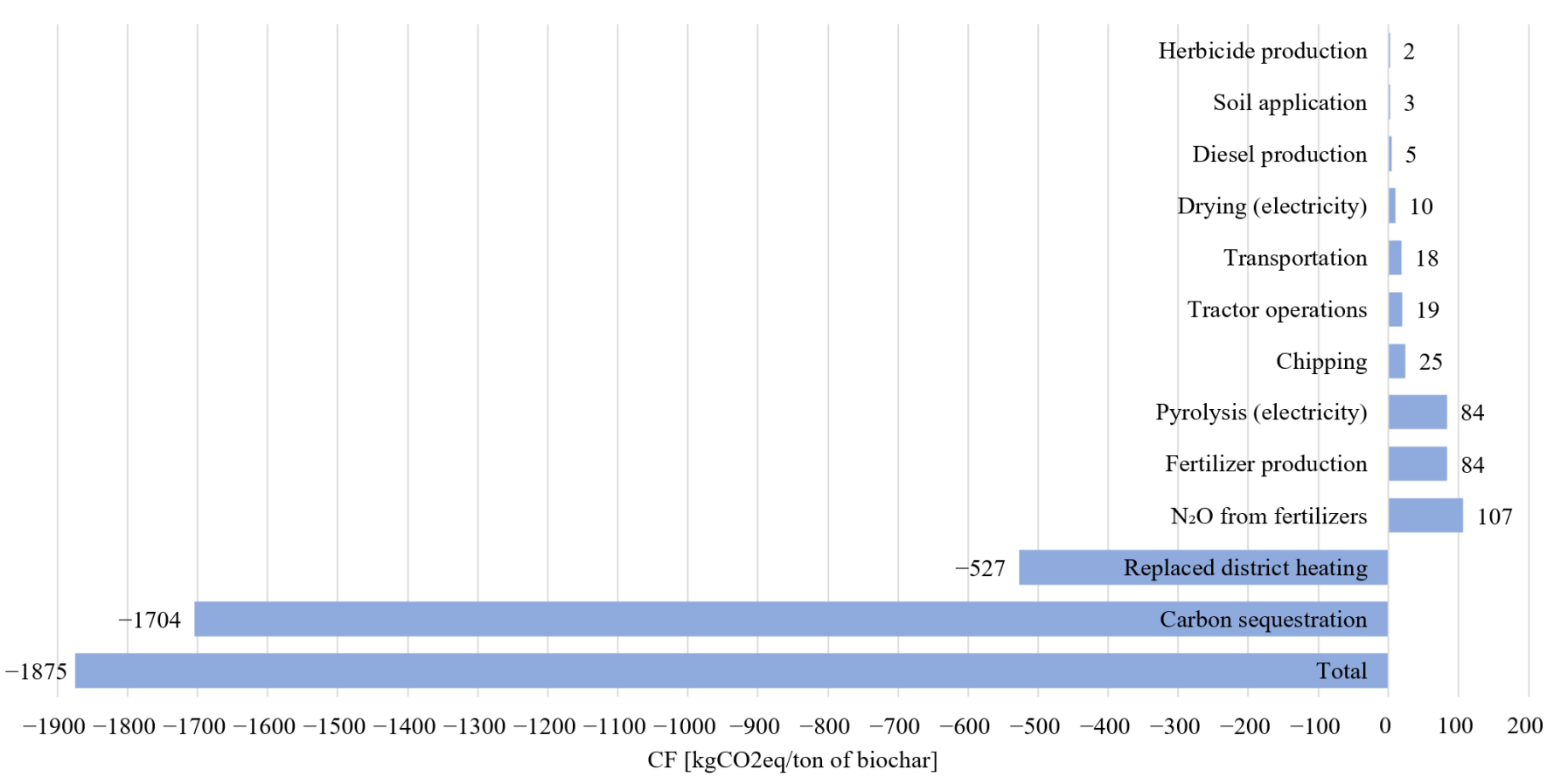

Figure 2. CF of processes during the willow biochar life cycle.

Storing the carbon in the ground had the biggest effect on the $\mathrm{CF}$ of the willow biochar life cycle. This result is, however, affected by some uncertain parameters, such as the carbon content of the biochar and the carbon stability in the ground. In addition, these parameters are affected by other parameters, such as the pyrolysis and soil conditions. Due to these uncertainties, the carbon content and stability and the biochar yield are studied next in the sensitivity analysis. Furthermore, the changes in the willow yield and excess heat utilization are also studied, as these parameters are likely to change depending on where the willow is cultivated and where the pyrolysis facility is located. For the willow yield, a sensitivity analysis is conducted according to the yield values found in the literature (5.8-8 $\mathrm{t} \mathrm{DM} \mathrm{ha}^{-1} \mathrm{a}^{-1}$ ). For the excess heat utilization, we attempted to determine the effect caused if the pyrolysis facility cannot be connected to the district heating network, and therefore the amount of heat for district heating is set to zero. For the biochar yield, the carbon content and the amount of stable carbon in percentual values are just increased and 
decreased by 10 percentage points to find out how sensitive the result is to the changes in these three parameters. The changes in the parameters and the results of the sensitivity analysis are presented in Table 1.

Table 1. Results of the sensitivity analysis. Values in brackets indicate how much results have changed compared to the original result of $-1875 \mathrm{kgCO}_{2}$ eq per $1 \mathrm{t}$ of biochar.

\begin{tabular}{ccc}
\hline Parameter. & Change & Result $\left[\mathbf{k g C O}_{\mathbf{2}}\right.$ eq per 1 t of Biochar] \\
\hline \multirow{2}{*}{ Willow yield } & $6.9 \rightarrow 8 \mathrm{t} \mathrm{DM} \mathrm{ha}^{-1} \mathrm{a}^{-1}$ & $-1904(-1.5 \%)$ \\
Heat to district heating & $6.9 \rightarrow 5.8 \mathrm{t} \mathrm{DM} \mathrm{ha}^{-1} \mathrm{a}^{-1}$ & $-1835(+2.1 \%)$ \\
Biochar yield & $3422 \rightarrow 0 \mathrm{kWh}$ & $-1348(+28.1 \%)$ \\
& $35 \rightarrow 25 \%$ & $-1946(-3.8 \%)$ \\
Carbon content & $35 \rightarrow 45 \%$ & $-1835(+2.1 \%)$ \\
\multirow{2}{*}{ Amount of stable carbon } & $72 \rightarrow 62 \%$ & $-1639(+12.6 \%)$ \\
& $72 \rightarrow 82 \%$ & $-2112(-12.6 \%)$ \\
\hline
\end{tabular}

Based on the sensitivity analysis, the CF of willow biochar rises significantly $(28 \%)$ when the pyrolysis unit is not connected to a district heating network. The possibility of utilizing the excess heat from the pyrolysis is dependent on the location of the facility. The amount of avoided emissions is also dependent on the fuel used in the district heating production.

The CF also seems to be sensitive to changes in the amount of stable carbon and the carbon content of the biochar. The CF decreases by $13 \%$ when the amount of stable carbon increases by $10 \%$ and decreases by $12.6 \%$ when the carbon content is increased by $10 \%$. These parameters are mostly affected by the pyrolysis conditions and the feedstock. For example, higher pyrolysis temperatures seem to increase the carbon content and the production of recalcitrant biochar. On the other hand, a higher pyrolysis temperature decreases the biochar yield [13,50].

Surprisingly, if the biochar yield decreases by $10 \%$, the CF drops by $3.8 \%$. This result can be explained by the increased amount of heat available for district heating, as more willow needs to be pyrolyzed to produce $1 \mathrm{t}$ of biochar. Changing the willow yield does not seem to affect the results much. The $1.1 \mathrm{t}$ increase in yield lowers $\mathrm{CF}$ only by $1.5 \%$.

In the assessment, it was assumed that excess heat can be utilized in district heating. This assumption led to a significant decrease in the CF, as the share of fossil fuels in district heating production in Finland is quite large. The emissions from pyrolysis were assumed to be zero, since the fuel used is renewable biomass, i.e., willow. However, the possibility of feeding excess heat to district heating is dependent on the location of the pyrolysis facility. When choosing the location for pyrolysis, the excess heat utilization possibilities should be mapped out. If there is no opportunity to utilize excess heat, it might be beneficial to use the heat to produce drier feedstocks to reduce the energy consumption of the pyrolysis process. Alternatively, it might be possible to pyrolyze moister feedstock, which would reduce the amount of excess heat, but also reduce the energy consumption of the drying process. An optimal scenario might be if the willow could be pyrolyzed straight after natural drying, when the moisture content is $26 \%$. However, pyrolyzing a higher moisture content feedstock increases the thermal loading and flow rates of the gases, and therefore larger systems for feeding and gas clean-up would be required [4].

The most emitting phase of the lifecycle was willow cultivation, where the production of fertilizers and $\mathrm{N}_{2} \mathrm{O}$ emissions were the main source of emissions. The amount of fertilizer needed could be reduced by using wastewater sludge as fertilizer, as in some places willows are already used in wastewater treatment [11]. However, this will probably not reduce the $\mathrm{N}_{2} \mathrm{O}$ emissions, since part of the added nitrogen would still be emitted as $\mathrm{N}_{2} \mathrm{O}$. Reducing emissions during tractor operations might be difficult, but some reductions can be achieved by using biofuels instead of conventional diesel. 
The results in this study match those presented in earlier studies and suggest that willow biochar has a negative CF. However, earlier studies, for example Hamedani et al. [15] and Hammond et al. [14], seem to suggest that an even lower CF could be achieved. In Hamedani et al. [15], the assessed CF of willow biochar was $-2200 \mathrm{kgCO}_{2} \mathrm{eq} \mathrm{t}$ of biochar ${ }^{-1}$. This value is $0.3 \mathrm{tCO}_{2} \mathrm{eq}$ lower than in this study. The work by Hamedani et al. [15] is quite similar to this study, the main differences being in the utilization of the excess heat and the biochar properties. Hamedani et al. [15] model the excess heat as being utilized in electricity production and use a biochar carbon content of $75 \%$ and stable carbon of $80 \%$. However, in the sensitivity analysis, it can be seen that when the share of stable carbon is raised to $78 \%$, the $\mathrm{CF}$ drops to $-2100 \mathrm{kgCO}_{2} \mathrm{eq}$, which is only $100 \mathrm{kgCO}_{2} \mathrm{eq}$ lower than the result in Hamedani et al. [15].

In the study by Hammond et al. [14], a total carbon abatement of 2.9-3.9 $\mathrm{tCO}_{2} \mathrm{eq} \mathrm{t}^{-1}$ of biochar was reached, which is significantly higher than in this study. Hammond et al. [14] consider the agricultural impacts of biochar in soil, which partly explains the greater abatement. According to their study, applying $30 \mathrm{t} \mathrm{ha}^{-1}$ of biochar to winter wheat crops delivers a $10 \%$ increase in net primary production, a $10 \%$ decrease in the rate of soil organic carbon decomposition, a $10 \%$ decrease in $\mathrm{N}$ fertilizer requirement, a $5 \%$ decrease in $\mathrm{P}$ and $\mathrm{K}$ fertilizer requirements, and a $25 \%$ suppression of soil $\mathrm{N}_{2} \mathrm{O}$ emissions. Agricultural impacts accounted for $18-22 \%$ of the carbon equivalent balance. The agricultural impacts of biochar were not included in this assessment because of the lack of measured data under Finnish conditions.

\subsection{Compensation Potential of Marginal Lands Used for Willow Cultivation}

The results of the LCA are now applied to assess the CF of marginal lands and buffer zones when they are used to grow willow for biochar production. The amount of marginal land in counties in Finland varies a lot depending on the location, as can be seen in Table 2. The greatest land masses are available in North Ostrobothnia (20,447 ha), Lapland (15,545 ha) and Kainuu (10,373 ha). These are some of the biggest counties in Finland, which might explain the large marginal land area. Additionally, North Ostrobothnia has the highest number of former peat production sites. The total area of marginal land in Finland is 118,685 ha [24]. If all these lands were to be utilized for producing willow biochar, a carbon sequestration potential of $500 \mathrm{kt} \mathrm{CO}_{2} \mathrm{eq} \mathrm{a}^{-1}$ would be achieved, which means that $7.7 \%$ of the yearly agricultural GHG emissions in Finland could be compensated. This value varies in the range of $1.9-36.1 \%$ in different counties. The greatest compensation potential is achieved in Kainuu, where agricultural emissions $\left(121 \mathrm{kt} \mathrm{CO}_{2} \mathrm{eq} \mathrm{a}{ }^{-1}\right)$ are relatively small compared with other counties and the area of marginal land is the third highest. In North Ostrobothnia, where agricultural emissions $\left(1048 \mathrm{kt} \mathrm{CO}_{2} \mathrm{eq} \mathrm{a}^{-1}\right)$ are highest, $9.3 \%$ of these emissions could be compensated with willow biochar from marginal land. The lowest compensation potential of $1.9 \%$ is found in Central Ostrobothnia, where the amount of marginal land (1537 ha) is lowest.

The amount of available marginal land is only an estimate, and it should be noted that all these lands might not be suitable for willow cultivation. Some of the available plots of land might be too small to be profitable places to cultivate willow, or the soil conditions might be too poor. Moreover, other options may exist for utilizing these lands that might be more attractive, such as the afforestation or cultivation of food crops. Further research should be done to investigate the profitability of willow cultivation on different sizes and types of land. 
Table 2. Amount of available marginal land in different counties in Finland and how much of the region's annual agricultural GHG emissions could be compensated with biochar from willow grown on marginal land $[24,62]$.

\begin{tabular}{|c|c|c|c|c|}
\hline County & $\begin{array}{c}\text { Agricultural } \\
\text { Emissions } 2018 \\
{\left[\mathrm{ktCO}_{2} \mathrm{eq} \mathrm{a}^{-1}\right]}\end{array}$ & $\begin{array}{l}\text { Marginal } \\
\text { Lands [ha] }\end{array}$ & $\begin{array}{c}\text { Carbon } \\
\text { Sequestration pot. } \\
{\left[\mathrm{ktCO}_{2} \text { eq a }^{-1}\right]}\end{array}$ & $\begin{array}{l}\text { Compensation } \\
\text { Potential [\%] }\end{array}$ \\
\hline $\begin{array}{l}\text { North } \\
\text { Ostrobothnia }\end{array}$ & 1048.4 & 20,447 & -86.2 & 8.2 \\
\hline Lapland & 320.1 & 15,545 & -65.5 & 20.5 \\
\hline Kainuu & 121.2 & 10,373 & -43.7 & 36.1 \\
\hline North Karelia & 293.6 & 8144 & -34.3 & 11.7 \\
\hline Central Finland & 273.7 & 7694 & -32.4 & 11.9 \\
\hline North Savo & 597.9 & 7547 & -31.8 & 5.3 \\
\hline Pirkanmaa & 371.8 & 7185 & -30.3 & 8.1 \\
\hline South Savo & 229.9 & 6901 & -29.1 & 12.7 \\
\hline Uusimaa & 226.5 & 6362 & -26.8 & 11.8 \\
\hline Southwest Finland & 466.5 & 5469 & -23.1 & 4.9 \\
\hline $\begin{array}{l}\text { South } \\
\text { Ostrobothnia }\end{array}$ & 873.3 & 5366 & -22.6 & 2.6 \\
\hline Satakunta & 315.4 & 4139 & -17.5 & 5.5 \\
\hline South Karelia & 143.6 & 3438 & -14.5 & 10.1 \\
\hline Kymenlaakso & 141.6 & 2407 & -10.1 & 7.2 \\
\hline Kanta-Häme & 199.2 & 2271 & -9.6 & 4.8 \\
\hline Päijät-Häme & 159.4 & 1950 & -8.2 & 5.2 \\
\hline Ostrobothnia & 393.7 & 1910 & -8.1 & 2.0 \\
\hline $\begin{array}{c}\text { Central } \\
\text { Ostrobothnia }\end{array}$ & 346.7 & 1537 & -6.5 & 1.9 \\
\hline Total & 6523.5 & 118,685 & -500.4 & 7.7 \\
\hline
\end{tabular}

To neutralize the emissions from a single field, a quite extensive area of willow cultivation is needed. According to Table 3, willow buffer zones in the range $0.20-1.13$ ha are required to neutralize the cultivation emissions of a 1-ha food crop field. The cultivation emissions of cereal crops (wheat, rye, barley, oat) are quite close to each other $\left(2330-1800 \mathrm{kgCO}_{2} \mathrm{eq} \mathrm{ha}^{-1}\right)$, as the cultivation procedures are very similar. The willow buffer zone required to neutralize these emissions is in the range $0.43-0.55$ ha. Fava bean has the smallest cultivation emissions $\left(828 \mathrm{kgCO}_{2} \mathrm{eq} \mathrm{ha}{ }^{-1}\right)$, and therefore the size of the required willow buffer zone ( $0.20 \mathrm{ha})$ is the smallest as well. As a nitrogen-fixing crop, fava bean does not require much nitrogen fertilizer, which reduces cultivation emissions significantly [26]. Cultivation emissions for spring rapeseed are $3170 \mathrm{kgCO}_{2} \mathrm{eq} \mathrm{ha}{ }^{-1}$, and the required willow buffer zone 0.75 ha. The biggest cultivation emissions are found with potato $\left(4760 \mathrm{kgCO}_{2} \mathrm{eq} \mathrm{ha}{ }^{-1}\right)$, and neutralizing those emissions would require a willow buffer zone that is more than the size of the cultivated field (1.13 ha).

Table 3. Cultivation emissions of different food crops $[25,26,28,29]$ and the size of the willow buffer zone needed for biochar production to neutralize these emissions.

\begin{tabular}{ccc}
\hline & Cultivation Emissions $\left[\mathbf{k g C O}_{\mathbf{2}} \mathbf{e q} \mathbf{h a}^{-\mathbf{1}}\right]$ & Willow Buffer Zone [ha] \\
\hline Wheat & 2330 & 0.55 \\
Rye & 2270 & 0.54 \\
Barley & 1930 & 0.46 \\
Oat & 1800 & 0.43 \\
Fava bean & 828 & 0.20 \\
Spring rapeseed & 3170 & 0.75 \\
Potato & 4760 & 1.13 \\
\hline
\end{tabular}


The creation of a carbon neutral field by growing willow for biochar production on a buffer zone would require an average buffer zone of $57 \%$ of the field size. Buffer zones of this size would be unreasonable because lots of arable land would be used for growing a non-food crop. To achieve a carbon-neutral field, additional means should be used together with willow biochar production. One possible solution could be producing biochar also from the side flows of the food crop cultivation, as presented in Uusitalo and Leino [16]. Even though a willow buffer zone alone will not make a field carbon-neutral, other benefits should also be considered. For example, a willow buffer zone can reduce nutrient leaching from the field, which in turn can reduce the eutrophication of local waterways [11].

When the CF of marginal lands and buffer zones as willow cultivation sites for biochar production are considered together, it can be seen that the total compensation potential varies a lot depending on the location and the cultivated crop. In some counties in Finland, growing willow for biochar production on marginal land is an attractive option, as over a third of the agricultural GHG emissions could be compensated. When willow cultivation on buffer zones is added, even higher compensation potentials could be achieved. However, to establish the full compensation potential in individual counties in Finland, the total area of buffer zones has to be investigated. Currently, no such data are available for Finland. Despite the missing buffer zone data, it is evident that implementing the production of willow biochar into agricultural practices could lower the carbon footprint of Finnish agriculture, even though full carbon neutrality could not be achieved by this measure alone.

Finally, a number of important limitations need to be considered. First, only the energy consumption of the machinery and facilities was considered in this study. In reality, part of the emissions from the production and maintenance of these machines should be allocated for the biochar, thereby increasing the total CF of the biochar life cycle. Secondly, only the ability of biochar to store carbon in soil was considered in this work. Some studies, such as Cayuela et al. [63], Jeffery et al. [64] and Jeffery et al. [65], state that biochar could also have an effect on soil emissions, fertilization and crop yields, which could offer some climate benefits. However, the magnitude of these soil effects is uncertain in the current literature, and they were therefore not considered. Thirdly, there is some uncertainty regarding the stability of biochar carbon in soil, as it depends on the soil conditions. The effect of carbon stability on the CF was examined in the sensitivity analysis, and it was found out that the result was quite sensitive to changes in carbon stability. Fourthly, the current usage of the marginal lands was not considered in this study. Some of the lands could already be sequestering carbon into biomass, and changing those land areas into willow fields might release the carbon that is sequestrated into them. Finally, it was assumed that willow can be grown on all marginal land and have the same yield. In reality, willow yields would vary depending on the land type, and some plots might not be large enough to cultivate willow profitably. When considering the profitability of the marginal land utilization, the opportunity costs should also be considered, as the land might already produce, for example, firewood for the owner. In addition to profitability, the effects of willow cultivation on biodiversity should also be studied, since marginal lands and buffer zones can be important maintainers of biodiversity in agricultural environments [66]. Notwithstanding these limitations, the results of the study are consistent with previous biochar LCA studies and support the idea of biochar as a carbon-negative product. These findings provide a possible approach to get a little closer to achieving carbon-neutral agriculture and the ultimate climate goal of keeping the temperature rise $1.5{ }^{\circ} \mathrm{C}$ below pre-industrial levels.

\section{Conclusions}

This study has extended our knowledge of the CF of willow biochar in Finland, considering it together with the total CF of marginal lands growing willow for biochar production. There is a definite need for assessing possible cultivation sites for these biomass-based solutions if the competition with food production and other sustainability issues are to be avoided. Based on the LCA conducted in this study, the CF of willow 
biochar is clearly negative. This result supports the literature's findings, according to which biochar is a carbon-negative product. When the LCA results were studied together with the marginal land potential in Finland, it was found that $7.7 \%$ of Finnish agricultural GHG emissions could be compensated if all marginal lands were used for growing willow for biochar production. When examining field buffer zones, it was seen that the average size of the buffer zones should be over $50 \%$ of the cultivated area if all cultivation emissions of food crops are to be neutralized.

The results of this study indicate that willow biochar produced from marginal lands can be used for compensating agricultural GHG emissions to some extent. However, to reach the full carbon neutrality of the agricultural sector in Finland, other means are also required, as the amount of marginal land in Finland is limited. Furthermore, other ways of utilizing marginal land exist that might be more attractive to landowners, such as forestry. The results of this paper can be used when evaluating possible uses for marginal land from the perspective of climate impacts. Further research might investigate the profitability of willow cultivation for biochar production, as the CF might not be the only interest of landowners and willow biochar could offer a landowner some additional income, and therefore help to maintain the vitality of rural areas. In addition to profitability, the effect on biodiversity of willow cultivation should also be studied, since marginal land plays an important role in maintaining the biodiversity in agricultural environments. The life cycle model built for this study can also be implemented when studying other uses for willow biochar because the first parts of the life cycle will be the same, and only simple changes to the last processes are needed. Other uses for biochar might be different kinds of filters and concrete additives.

The results of this work raise many interesting questions, and, for example, further research is needed to determine the other soil effects of biochar usage. Some literature sources mention that biochar could reduce fertilizer needs and increase crop yields. However, there is a lot of variation in these reported effects, and they were therefore excluded from the study. If the effects of biochar in soil are better known, more precise life cycle models can be built. Further study could also assess the carbon stability of biochar in soils so that the $\mathrm{CF}$ of the biochar can be predicted more reliably. Even though the possible effects on soil were excluded in this work, the cultivation of willow, biochar production and storage in soil appear to be competent mechanisms to remove carbon dioxide from the atmosphere to long-term storage, thus supporting the $1.5^{\circ} \mathrm{C}$ climate target.

Author Contributions: Conceptualization, L.L., M.P.M., V.U. and J.L.; methodology, L.L., M.P.M. and V.U.; software, L.L.; validation, L.L., M.P.M. and V.U.; formal analysis, L.L.; investigation, L.L.; resources, L.L.; data curation, L.L.; writing—original draft preparation, L.L.; writing-review and editing, L.L., M.P.M., V.U., J.L., V.H. and M.H.M.; visualization, L.L.; supervision, V.U., M.H.M. and M.P.M.; project administration, M.H.M.; funding acquisition, M.H.M. All authors have read and agreed to the published version of the manuscript.

Funding: The research was funded by the European Agricultural Fund for Rural Development.

Institutional Review Board Statement: Not applicable.

Informed Consent Statement: Not applicable.

Data Availability Statement: All the data are available within this manuscript.

Acknowledgments: This work was carried out as part of the HIME project, funded by the European Agricultural Fund for Rural Development.

Conflicts of Interest: The authors declare no conflict of interest. The funders had no role in the design of the study; in the collection, analyses, or interpretation of data; in the writing of the manuscript, or in the decision to publish the results. 


\section{Appendix A}

Table A1. Life cycle inventory. Inputs and outputs of each process presented per functional unit and data sources.

\begin{tabular}{|c|c|c|c|c|}
\hline Process & Input/Output Flow & Unit & Amount & Data Source \\
\hline \multirow[t]{10}{*}{ Cultivation } & Inputs & & & \\
\hline & Diesel & $\mathrm{kg}$ & 5.55 & [36-38] \\
\hline & Nitrogen & $\mathrm{kg}$ & 25.61 & [41] \\
\hline & Phosphorus pentoxide & $\mathrm{kg}$ & 8.22 & {$[41]$} \\
\hline & Potassium oxide & $\mathrm{kg}$ & 22.22 & [41] \\
\hline & Glyphosate & 1 & 0.16 & {$[34,39]$} \\
\hline & Metazachlor & 1 & 0.03 & [34] \\
\hline & Outputs & & & \\
\hline & Willow rods (52\% moist.) & $\mathrm{kg}$ & 6136.48 & [30-32] \\
\hline & $\mathrm{N}_{2} \mathrm{O}$ emissions & $\mathrm{kg}$ & 0.40 & [67] \\
\hline \multirow[t]{4}{*}{ Natural drying } & Inputs & & & \\
\hline & Willow rods (52\% moist.) & $\mathrm{kg}$ & 6136.48 & Calculated \\
\hline & Outputs & & & \\
\hline & Willow rods (26\% moist.) & $\mathrm{kg}$ & 3861.00 & {$[40,44]$} \\
\hline \multirow[t]{6}{*}{$\begin{array}{l}\text { Roadside } \\
\text { chipping }\end{array}$} & Inputs & & & \\
\hline & Willow rods (26\% moist.) & $\mathrm{kg}$ & 3861.00 & Calculated \\
\hline & Diesel & $\mathrm{kg}$ & 7.63 & [47] \\
\hline & Outputs & & & \\
\hline & Willow chips ( $26 \%$ moist.) & $\mathrm{kg}$ & 3861.00 & Calculated \\
\hline & $\mathrm{CO}_{2}$ emissions & $\mathrm{kg}$ & 24.55 & [43] \\
\hline Transportation & Transport distance & $\mathrm{km}$ & 68.00 & [48] \\
\hline \multirow[t]{6}{*}{ Artificial drying } & Inputs & & & \\
\hline & Willow chips ( $26 \%$ moist.) & $\mathrm{kg}$ & 3861.00 & Calculated \\
\hline & Heat energy & kWh & 858.69 & {$[45,46]$} \\
\hline & Electricity & $\mathrm{kWh}$ & 48.05 & {$[45,46]$} \\
\hline & Outputs & & & \\
\hline & Dried willow chips ( $10 \%$ moist.) & $\mathrm{kg}$ & 3174.60 & \\
\hline \multirow[t]{7}{*}{ Slow pyrolysis } & Inputs & & & \\
\hline & Dried willow chips ( $10 \%$ moist.) & $\mathrm{kg}$ & 3174.60 & {$[53,54]$} \\
\hline & Electricity & kWh & 400.00 & {$[51,52]$} \\
\hline & Outputs & & & \\
\hline & Dry biochar & $\mathrm{kg}$ & 1000.00 & Calculated \\
\hline & Excess heat to artificial drying & kWh & 858.69 & {$[53,54]$} \\
\hline & Excess heat to district heating & $\mathrm{kWh}$ & 3422.25 & {$[53,54]$} \\
\hline \multirow{5}{*}{$\begin{array}{c}\text { Biochar } \\
\text { moistening }\end{array}$} & Inputs & & & \\
\hline & Dry biochar & $\mathrm{kg}$ & 1000.00 & Calculated \\
\hline & Water & $\mathrm{kg}$ & 176.47 & [57] \\
\hline & Outputs & & & \\
\hline & Wet biochar (15\% moist.) & $\mathrm{kg}$ & 1176.47 & Calculated \\
\hline Transportation & Transport & $\mathrm{km}$ & 68.00 & [48] \\
\hline \multirow[t]{5}{*}{$\begin{array}{c}\text { Soil } \\
\text { amendment }\end{array}$} & Inputs & & & \\
\hline & Diesel & $\mathrm{kg}$ & 0.81 & {$[37,59]$} \\
\hline & Wet biochar & $\mathrm{kg}$ & 1176.47 & Calculated \\
\hline & Outputs & & & \\
\hline & Wet biochar in soil & $\mathrm{kg}$ & 1176.47 & Calculated \\
\hline
\end{tabular}


Table A2. Fuel consumption of each tractor operation and how often each operation is implemented during the plantation lifetime (25 years).

\begin{tabular}{cccc}
\hline Process & $\begin{array}{c}\text { Frequency } \\
\text { [Times Lifetime }\end{array}$ & $\begin{array}{c}\text { Fuel Consumption } \\
{\left[\mathbf{l ~ h a}^{\mathbf{- 1}}\right]}\end{array}$ & Reference \\
\hline Ploughing & 1 & 23.97 & {$[36-38]$} \\
Power harrowing & 1 & 6.00 & {$[37]$} \\
Rolling & 1 & 3.64 & {$[37,38]$} \\
Herbicide spraying & 3 & 2.03 & {$[37,38]$} \\
Fertilization & 6 & 2.00 & {$[37]$} \\
Planting & 1 & 10.60 & {$[38]$} \\
Harvesting & 6 & 50.00 & {$[38]$} \\
Mulching & 1 & 12.90 & {$[37]$} \\
\hline
\end{tabular}

\section{References}

1. Haszeldine, R.S.; Flude, S.; Johnson, G.; Scott, V. Negative emissions technologies and carbon capture and storage to achieve the Paris Agreement commitments. Philos. Trans. R. Soc. Math. Phys. Eng. Sci. 2018, 376, 20160447. [CrossRef]

2. Smith, P.; Davis, S.J.; Creutzig, F.; Fuss, S.; Minx, J.; Gabrielle, B.; Kato, E.; Jackson, R.B.; Cowie, A.; Kriegler, E.; et al. Biophysical and economic limits to negative $\mathrm{CO}_{2}$ emissions. Nat. Clim. Chang. 2016, 6, 42-50. [CrossRef]

3. Smith, P. Soil carbon sequestration and biochar as negative emission technologies. Glob. Chang. Biol. 2016, 22, 1315-1324. [CrossRef]

4. Lehmann, J.; Joseph, S. Biochar for Environmental Management: Science and Technology; Earthscan: London, UK, 2009; ISBN 978-1-84407-658-1.

5. Zhang, C.; Zeng, G.; Huang, D.; Lai, C.; Chen, M.; Cheng, M.; Tang, W.; Tang, L.; Dong, H.; Huang, B.; et al. Biochar for environmental management: Mitigating greenhouse gas emissions, contaminant treatment, and potential negative impacts. Chem. Eng. J. 2019, 373, 902-922. [CrossRef]

6. Paustian, K.; Lehmann, J.; Ogle, S.; Reay, D.; Robertson, G.P.; Smith, P. Climate-smart soils. Nature 2016, 532, 49-57. [CrossRef]

7. Jawad, S. The Cumulative Benefits of Biochar in Agriculture. Bachelor's Thesis, KTH Royal Institute of Technology, Stockholm, Sweden, 2018.

8. Söderqvist, H. Carbon Stability of Biochar Methods for Assessment and Indication. Master's Thesis, KTH Royal Institute of Technology, Stockholm, Sweden, 2019.

9. Qian, X.; Xue, J.; Yang, Y.; Lee, S.W. Thermal Properties and Combustion-Related Problems Prediction of Agricultural Crop Residues. Energies 2021, 14, 4619. [CrossRef]

10. Qian, X. Statistical Analysis and Evaluation of the Advanced Biomass and Natural Gas Co-Combustion Performance. Ph.D. Thesis, Morgan State University, Baltimore, MD, USA, 2019.

11. Pohjonen, V. Pajukko Nielee, Hiilen ja Pääravinteiden Kierrätys Biomassapajuilla. Available online: https:/ / pohjonen.org/veli/ vprefs /2016/2016\%2010\%2025\%20Veli\%20Pohjonen\%20Pajukko\%20nielee.pdf (accessed on 21 March 2021).

12. Rasa, K.; Heikkinen, J.; Hannula, M.; Arstila, K.; Kulju, S.; Hyväluoma, J. How and why does willow biochar increase a clay soil water retention capacity? Biomass Bioenerg. 2018, 119, 346-353. [CrossRef]

13. Tisserant, A.; Cherubini, F. Potentials, limitations, co-benefits, and trade-offs of biochar applications to soils for climate change mitigation. Land 2019, 8, 179. [CrossRef]

14. Hammond, J.; Shackley, S.; Sohi, S.; Brownsort, P. Prospective life cycle carbon abatement for pyrolysis biochar systems in the UK. Energy Policy 2011, 39, 2646-2655. [CrossRef]

15. Hamedani, S.R.; Kuppens, T.; Malina, R.; Bocci, E.; Colantoni, A.; Villarini, M. Life cycle assessment and environmental valuation of biochar production: Two case studies in belgium. Energies 2019, 12, 2166. [CrossRef]

16. Uusitalo, V.; Leino, M. Neutralizing global warming impacts of crop production using biochar from side flows and buffer zones: A case study of oat production in the boreal climate zone. J. Clean. Prod. 2019, 227, 48-57. [CrossRef]

17. Runge, C.F.; Senauer, B. How biofuels could starve the poor. Foreign Aff. 2007, 86, 41-53.

18. Searchinger, T.; Heimlich, R.; Houghton, R.A.; Dong, F.; Elobeid, A.; Fabiosa, J.; Tokgoz, S.; Hayes, D.; Yu, T.-H. Use of U.S. croplands for biofuels increases greenhouse gases through emissions from land-use change. Science 2008, 319, 1238-1240. [CrossRef]

19. Qin, Z.; Zhuang, Q.; Zhu, X.; Cai, X.; Zhang, X. Carbon consequences and agricultural implications of growing biofuel crops on marginal agricultural lands in China. Environ. Sci. Technol. 2011, 45, 10765-10772. [CrossRef]

20. Skevas, T.; Swinton, S.M.; Hayden, N.J. What type of landowner would supply marginal land for energy crops? Biomass Bioenerg. 2014, 67, 252-259. [CrossRef]

21. Finnish Standards Association SFS. Environmental Management. Life Cycle Assessment. Principles and Framework; SFS-EN ISO 14040:2006; Approved 18 December 2006; Finnish Standards Association SFS: Helsinki, Finland, 2006.

22. Finnish Standards Association SFS. Environmental Management. Life Cycle Assessment. Requirements and Guidelines; SFS-EN ISO 14044:2006; Approved 18 December 2006; Finnish Standards Association SFS: Helsinki, Finland, 2006.

23. Finnish Standards Association SFS. Greenhouse Gases. Carbon Footprint of Products. Requirements and Guidelines for Quantification; SFS-EN ISO 14067:2018; Approved 5 October 2018; Finnish Standards Association SFS: Helsinki, Finland, 2018. 
24. Lumperoinen, M.; Hämäläinen, M. Metsitys Kestävästi 2020, Joutoalueiden Määrittäminen—Paikkatietoanalyysin Tulokset, 24.4.2020. Tapio. Available online: https://mmm.fi/documents/1410837/22015134/Arvio+joutoalueiden+metsityspotentiaalista+ 24_04_2020.pdf/a34c023e-4dd6-e40d-bc57-2bf8d5a4f2a2/Arvio+joutoalueiden+metsityspotentiaalista+24_04_2020.pdf (accessed on 21 March 2021).

25. Rajaniemi, M.; Mikkola, H.; Ahokas, J. Greenhouse gas emissions from oats, barley, wheat and rye production. Agron. Res. 2011, 9, 189-195.

26. Heusala, H.; Sinkko, T.; Sözer, N.; Hytönen, E.; Mogensen, L.; Knudsen, M.T. Carbon footprint and land use of oat and faba bean protein concentrates using a life cycle assessment approach. J. Clean. Prod. 2020, 242, 118376. [CrossRef]

27. Natural Resources Institute Finland. Luke Official Variety Trials. Available online: https://www.luke.fi/avoin-tieto/maa-jaelintarviketalous/uusien-peltokasvilajikkeiden-viljelyarvo/ (accessed on 23 March 2021).

28. Fridrihsone, A.; Romagnoli, F.; Cabulis, U. Environmental life cycle assessment of rapeseed and rapeseed oil produced in Northern Europe: A Latvian case study. Sustainability 2020, 12, 5699. [CrossRef]

29. Pulkkinen, H.; Kemppainen, M.; Markus, A.; Virtanen, E. Perunan Ilmastovaikutukset. MTT Raportti; MTT Jokioinen. Available online: https://jukuri.luke.fi/bitstream/handle/10024/438285/mttraportti73.pdf?sequence=1\&isAllowed=y (accessed on 23 March 2021).

30. Mola-Yudego, B. Regional potential yields of short rotation willow plantations on agricultural land in Northern Europe. Silva. Fenn. 2010, 44, 63-76. [CrossRef]

31. Laasasenaho, K.; Lensu, A.; Rintala, J.; Lauhanen, R. Landowners' willingness to promote bioenergy production on wastelandFuture impact on land use of cutaway peatlands. Land Use Policy 2017, 69, 167-175. [CrossRef]

32. Pajupojat Oy-WillowPartners. Ravinteiden Kierrätyksen Edistämistä ja Saaristomeren Tilan Parantamista Koskeva Hanke: Pajureaktorit, Pajupojat Oy-WillowPartners, Loppuraportti. Available online: https://www.ym.fi/download/noname/\%7B451 4563C-EDB0-4361-895F-9EC022900F14\%7D/129347 (accessed on 23 March 2021).

33. Alakangas, E.; Hurskainen, M.; Laatikainen-Luntama, J.; Korhonen, J. Suomessa Käytettävien Polttoaineiden Ominaisuuksia. VTT Technical Research Centre of Finland, 2016, 263. Available online: https:/ /www.vttresearch.com/sites/default/files/pdf/ technology /2016/T258.pdf (accessed on 23 March 2021).

34. Niemi, A. Energiapajun Viljely ja Käyttö Vesien Puhdistuksessa-Teknis-Taloudellinen Tarkastelu. Master's Thesis, University of Jyväskylä, Jyväskylä, Finland, 2014.

35. Hytönen, J. Biomass Production and Nutrition of Short Rotation Plantations; The Finnish Forest Research Institute: Kannus, Finland, 1996; Volume 61.

36. Ahokas, J. Polttoaineen Kulutus Peltotöissä; University of Helsinki: Helsinki, Finland, 2013; ISBN 978-952-10-8885-8.

37. Handler, F.; Nadlinger, M. D 3.8 Strategies for Saving Fuel with Tractors, Trainer Handbook; EU Projekt Intelligent Energy Europe, Efficient 20, IEE/09/764/SI2.558250; European Commission: Brussels, Belgium, 2012.

38. Murphy, F.; Devlin, G.; McDonnell, K. Energy requirements and environmental impacts associated with the production of short rotation willow (Salix sp.) chip in Ireland. GCB Bioenergy 2014, 6, 727-739. [CrossRef]

39. Caslin, B.; Finnan, J.; Johnston, C.; McCracken, A.; Walsh, L. Short Rotation Coppice Willow, Best Practice Guidelines; Teagasc, Agriculter and Food Development Authority: Carlow, Ireland, 2015; Volume 128, ISBN 1-84170-610-8.

40. Sihvonen, J.; Leinonen, A.; Villa, A. Pajun Korjuu, Varastointija Toimitus Laitokselle—Tehtäväraportti; VTT Technical Research Centre of Finland: Jyväskylä, Finland, 2013.

41. Tahvanainen, L. Pajun Viljelyn Perusteet; Joensuun Yliopisto: Joensuu, Finland, 1995; ISBN 951-708-308-4.

42. European Commission Regulation (EC) No 2003/2003 of the European Parliament and of the Council of 13 October 2003 relating to fertilizers. Off. J. Eur. Communities 2003. Available online: http://data.europa.eu/eli/reg/2003/2003/oj (accessed on 8 September 2021).

43. IPCC. 2006 IPCC Guidelines for National Greenhouse Gas Inventories. 2006. Available online: https:/ /www.ipcc-nggip.iges.or. jp/public/2006gl/vol2.html (accessed on 21 March 2021).

44. Nurmi, J. The effect of whole-tree storage on the fuelwood properties of short-rotation Salix crops. Biomass Bioenerg 1995, 8 , 245-249. [CrossRef]

45. Roitto, J. Puuhakkeen Käsittely- ja Poltto-Ominaisuuksien Parantaminen. Master's Thesis, LUT University, Lappeenranta, Finland, 2014.

46. Pääkkönen, P. Kuivuritekniikan Selvitys. Micropolis: Ii, Finland, 2020, 35. Available online: https://docplayer.fi/18487143 -Kuivuritekniikan-selvitys-dokumentti-nro.html (accessed on 8 September 2021).

47. Spinelli, R.; Magagnotti, N.; Paletto, G.; Preti, C. Determining the impact of some wood characteristics on the performance of a mobile chipper. Silva. Fenn. 2011, 45, 85-95. [CrossRef]

48. Statistics Finland. Tieliikenteen Tavarankuljetukset, Liitetaulukko 10. Keskimääräinen Kuljetusmatka ja Kuormausaste Kotimaan Liikenteessä Tavaralajeittain Vuonna. 2017. Available online: http://www.stat.fi/til/kttav/2017/kttav_2017_2018-04-26_tau_01 0_fi.html (accessed on 18 May 2020).

49. Mohan, D.; Sarswat, A.; Ok, Y.S.; Pittman, C.U. Organic and inorganic contaminants removal from water with biochar, a renewable, low cost and sustainable adsorbent-A critical review. Bioresour. Technol. 2014, 160, 191-202. [CrossRef] [PubMed]

50. Crombie, K.; Mašek, O. Investigating the potential for a self-sustaining slow pyrolysis system under varying operating conditions. Bioresour. Technol. 2014, 162, 148-156. [CrossRef] 
51. Harsono, S.S.; Grundman, P.; Lau, L.H.; Hansen, A.; Salleh, M.A.M.; Meyer-Aurich, A.; Idris, A.; Ghazi, T.I.M. Energy balances, greenhouse gas emissions and economics of biochar production from palm oil empty fruit bunches. Resour. Conserv. Recycl. 2013, 77, 108-115. [CrossRef]

52. Lu, H.R.; El Hanandeh, A. Assessment of bioenergy production from mid-rotation thinning of hardwood plantation: Life cycle assessment and cost analysis. Clean Technol. Environ. Policy 2017, 19, 2021-2040. [CrossRef]

53. Klinar, D. Universal model of slow pyrolysis technology producing biochar and heat from standard biomass needed for the techno-economic assessment. Bioresour. Technol. 2016, 206, 112-120. [CrossRef]

54. Roberts, K.G.; Gloy, B.A.; Joseph, S.; Scott, N.R.; Lehmann, J. Life cycle assessment of biochar systems: Estimating the energetic, economic, and climate change potential. Environ. Sci. Technol. 2010, 44, 827-833. [CrossRef]

55. Alakangas, E.; Impola, R. Puupolttoaineiden Laatuohje; Bioenergia ry: Helsinki, Finland, 2014; ISBN 978-952-93-3223-6.

56. Motiva. $\mathrm{CO}_{2}$-Päästökertoimet. Available online: https://www.motiva.fi/ratkaisut/energiankaytto_suomessa/co2-laskentaohje_ energiankulutuksen_hiilidioksidipaastojen_laskentaan/co2-paastokertoimet (accessed on 21 July 2020).

57. Major, J. Guidelines on Practical Aspects of Biochar Application to Field Soil in Various Soil Management Systems; International Biochar Initiative: Westerville, OH, USA, 2010; Volume 23, Available online: https:/ /www.biochar-international.org/wp-content/ uploads/2018/04/IBI_Biochar_Application.pdf (accessed on 21 July 2020).

58. Silva, F.C.; Borrego, C.; Keizer, J.J.; Amorim, J.H.; Verheijen, F.G.A. Effects of moisture content on wind erosion thresholds of biochar. Atmos. Environ. 2015, 123, 121-128. [CrossRef]

59. Brandstaka, T.; Helenius, J.; Hovi, J.; Kivelä, J.; Koppelmäki, K.; Simojoki, A.; Soinne, H.; Tammeorg, P. Biochar Filter: Use of Biochar in Agriculture as Soil Conditioner; Baltic Sea Action Summit; University of Helsinki: Helsinki, Finland, 2010.

60. Mašek, O.; Budarin, V.; Gronnow, M.; Crombie, K.; Brownsort, P.; Fitzpatrick, E.; Hurst, P. Microwave and slow pyrolysis biochar-Comparison of physical and functional properties. J. Anal. Appl. Pyrolysis 2013, 100, 41-48. [CrossRef]

61. Ronsse, F.; van Hecke, S.; Dickinson, D.; Prins, W. Production and characterization of slow pyrolysis biochar: Influence of feedstock type and pyrolysis conditions. GCB Bioenergy 2013, 5, 104-115. [CrossRef]

62. Finnish Environment Institute. SYKE—Kuntien ja Alueiden Khk-Päästöt. Available online: https://paastot.hiilineutraalisuomi.fi/ (accessed on 21 October 2020).

63. Cayuela, M.L.; van Zwieten, L.; Singh, B.P.; Jeffery, S.; Roig, A.; Sánchez-Monedero, M.A. Biochar's role in mitigating soil nitrous oxide emissions: A review and meta-analysis. Agric. Ecosyst. Environ. 2014, 191, 5-16. [CrossRef]

64. Jeffery, S.; Verheijen, F.G.A.; van der Velde, M.; Bastos, A.C. A quantitative review of the effects of biochar application to soils on crop productivity using meta-analysis. Agric. Ecosyst. Environ. 2011, 144, 175-187. [CrossRef]

65. Jeffery, S.; Verheijen, F.G.A.; Kammann, C.; Abalos, D. Biochar effects on methane emissions from soils: A meta-analysis. Soil Biol. Biochem. 2016, 101, 251-258. [CrossRef]

66. Ministry of the Environment. Luonnon Monimuotoisuudelle Haitalliset Tuet, Taustaselvitys; Ministry of Environment: Helsinki, Finland, 2015; ISBN 978-952-11-4450-9.

67. FAO, Food and Agriculture Organization of the United Nations. Global Database of GHG Emissions Related to Feed Crops: Methodology; Version 1; Livestock Environmental Assessment and Performance Partnership: Rome, Italy, 2017. 